\title{
The Income Inequality and Domestic Terrorism Nexus: Fresh Evidence from Pakistan
}

\author{
Muhammad Shahbaz* \\ COMSATS Institute of Information Technology, Lahore-54000, Pakistan \\ Faridul Islam \\ Department of Economics, Morgan State University, Baltimore, MD 21251. \\ Muhammad Sabihuddin Butt \\ Applied Economic Research Centre, Islamabad-44000, Pakistan
}

\begin{abstract}
:
We examine the relationship among income inequality and domestic terrorism economic

growth, education and trade openness. Results indicate that rise in income-inequality promotes terrorism. Lopsided economic growth and unequal access to education accentuate inequality and contribute to terrorism.
\end{abstract}

Keywords: Inequality, Terrorism, Pakistan 


\section{Introduction}

Why some people turn terrorists, destroy property and innocent lives; and even take their own, when it produces nothing good? Terrorist activities cause substantial economic and political damage (Frey et al. 2007). The paper examines the nexus of domestic terrorism, income inequality, per-capita economic growth, education, and trade openness. The latter two variables can contribute to inequality. Research shows that terrorists are more likely to originate from low-income countries (Blomberg et al. 2004; Abadie, 2006; Kurrild-Klitgaard et al. (2006); and Barros et al. 2008). However, Piazza (2006) finds no such relationship. Perhaps, substantial expenditure on socialwelfare programs by affluent nations dissuades people from terrorism (Burgoon, 2006). Freytag et al. (2011) offer mixed evidence (Caruso and Schneider (2013) for more).

Aside economic factor, some studies have linked terrorism to political instability and repression. However, but the significance of inequality has remained largely unexplored (Krieger et at. 2011). The pervasive nature of poverty and terrorism in Pakistan makes it an interesting case-study. The findings should help policymakers identify preventive measures.

Income inequality and discrimination can breed instability by creating a strong sense of economic disenfranchisement and a ground for violent response against the status-quo. When people feel dispossessed, they are left with little option to non-violent means, making terrorism attractive (Ross, 1993). Economically, the payoff for abatement of domestic terrorism can be high, but has not been considered in the extant literature.

Section-II describes data sources. Section-III presents estimation strategy. Section-IV reports results. Conclusion and policy implications are offered in section-V.

\section{The Data and Model Construction}

The study period covers1972-2010, the data on income inequality is from Jamal. (2005), extrapolated to 2010. Data on secondary (basic) education, real GDP per-capita $(2000=100)$, real trade per capita [(exports+imports)/population] and prices are from the Government of Pakistan (GoP) (2012). The terrorism series has been constructed by using descriptive data (attacks in Pakistan) compiled chronologically, by the Institute of Conflict Management, India.

We posit the following relation to investigate the impact of income inequality, economic growth, education and trade openness on domestic terrorism:

$\ln T E R_{t}=\alpha_{1}+\alpha_{I} \ln I_{t}+\alpha_{Y} \ln Y_{t}+\alpha_{E} \ln E_{t}+\alpha_{T O} \ln T O_{t}+\mu_{i}$

Where, ${ }^{T E R_{t}}$ is domestic terrorists attacks; ${ }_{t}$ income inequality proxied by Gini-coefficient; ${ }^{t}$ real GDP per-capita; $E_{t}$ education per-capita; $T O_{t}$ trade openness per-capita, and ${ }^{\mu}$ the error term assumed $N\left(0, \sigma^{2}\right)$. All series are transformed in natural logarithm. 
Although high inequality does not necessarily produce terrorists, the former can facilitate radical environment for the latter to thrive. We expect $\alpha_{I}>0$. The impact of economic growth on terrorism is uncertain. High income societies are less prone to terrorism because of high opportunity costs of violence due to stronger social services economies dampening terrorism, $\left(\alpha_{Y}<0\right.$ ) and conversely. Adverse socioeconomic, political and demographic conditions favor violence; $\alpha_{Y}>0$. Trade openness promotes economic growth and economic growth generates employment opportunities which should lower terrorism () $\alpha_{T O}<0$. However, trade openness can worsen inequality, $\alpha_{T O}>0$ (see Bhagwatietal.2004).

\section{Estimation}

We implement the ARDL bounds testing approach [Pesaran et al. 2001] to cointegration because of its advantages over the others methods. The test involves estimating the following Unrestricted Error-Correction Model (UECM):

$$
\begin{aligned}
\Delta \ln T E R_{t}= & b_{0}+\sum_{i=1}^{p} c_{i} \Delta \ln T E R_{t-i}+\sum_{i=0}^{p} d_{i} \Delta \ln I_{t-i}+\sum_{i=0}^{p} e_{i} \Delta \ln Y_{t-i}+\sum_{i=0}^{p} f_{i} \Delta \ln E_{t-i}++\sum_{i=0}^{p} g_{i} \Delta \ln T O_{t-i} \\
& +\pi_{1} \ln T E R_{t-1}+\pi_{2} \ln I_{t-1}+\pi_{3} \ln Y_{t-1}+\pi_{4} \ln E_{t-1}+\pi_{5} \ln T O+u_{t}
\end{aligned}
$$

Where $\Delta$ is-different operator, ${ }^{b}{ }_{0}$ the drift component, $p$ maximum lag, and ${ }^{u_{t}}$ white-noise process. We use the F-test for joint significance of lagged level variables. The null hypothesis of no co integration, $H_{0}: \pi_{1}=\pi_{2}=\pi_{3}=\pi_{4}=\pi_{5}=0$; is tested against the alternate $\left(H_{a}: \pi_{1} \neq \pi_{2} \neq \pi_{3} \neq \pi_{4} \neq \pi_{5} \neq 0\right.$ ). We compare the computed F-statistic with the tabulated values - the upper critical bounds (UCB) and the lower critical bounds (LCB). If the F-statistic exceeds UCB, we reject the null hypothesis; and if it falls below LCB, there is no co-integration. If $\mathrm{F}$ is between the two bounds, the decision is inconclusive. After choosing the optimal lag order, we estimate the long and short run parameters. A negative but statistically significant lagged error correction term $\left(\mathrm{ECM}_{\mathrm{t}-1}\right)$ ensures that any short run deviation converges to the long-run equilibrium. Diagnostic tests check for serial correlation, nonnormality, heteroscedasticity and functional form. The stability tests are based on the cumulative sum recursive residuals (CUSUM) and cumulative sum of squares residuals (CUSUM $\mathrm{SQ}_{\mathrm{SQ}}$ ).

\section{Results and Discussion}

Pakistan saw major changes in the political landscape which might cause structural break in the series. So, we apply the Lee and Strazicich (2004) unit root test. The results, reported in Table-1 suggest that each series is (1), with intercept and trend in the presence of structural breaks. 
Table-1: Results of Lee-Strazicich Unit-root test with one/two structural breaks

\begin{tabular}{|c|c|c|c|c|c|c|c|c|}
\hline \multicolumn{9}{|c|}{ Model: Trend-Break Model } \\
\hline \multirow[b]{2}{*}{ Series } & \multicolumn{4}{|c|}{ Level-data } & \multicolumn{4}{|c|}{ First-difference } \\
\hline & $\mathrm{T}_{\mathrm{B} 1}$ & $\mathrm{~T}_{\mathrm{B} 2}$ & Test statistics & $\mathrm{K}$ & $\mathrm{T}_{\mathrm{B} 1}$ & $\mathrm{~T}_{\mathrm{B} 2}$ & Test statistics & K \\
\hline \multirow{2}{*}{$\ln T E R_{t}$} & 1997 & & -3.2826 & 0 & 2002 & & $-7.4769 *$ & 1 \\
\hline & 1978 & 2000 & -2.0143 & 1 & 1984 & 1988 & $-14.2398^{*}$ & 1 \\
\hline \multirow{2}{*}{$\ln I_{t}$} & 1998 & & -2.1135 & 3 & 2002 & & $-5.2001 * *$ & 1 \\
\hline & 1986 & 1999 & -3.5595 & 4 & 1998 & 2002 & $-10.0845^{*}$ & 1 \\
\hline \multirow[t]{2}{*}{$\ln Y_{t}$} & 1997 & & -2.4853 & 0 & 1989 & & $-5.7574 *$ & 0 \\
\hline & 1983 & 2007 & -3.7342 & 4 & 1981 & 2002 & $-5.9551 *$ & 0 \\
\hline \multirow{2}{*}{$\ln E_{t}$} & 2001 & & -2.8632 & 2 & 2002 & & $-7.8666 *$ & 3 \\
\hline & 1990 & 2001 & -1.5599 & 4 & 1995 & 2002 & $-13.5617^{*}$ & 4 \\
\hline \multirow[t]{2}{*}{$\ln T O_{t}$} & 2003 & & -1.9997 & 1 & 1999 & & $-5.1443 * *$ & 0 \\
\hline & 1996 & 2003 & -3.0818 & 3 & 1995 & 2003 & $-6.3963 *$ & 3 \\
\hline
\end{tabular}

Note: $T_{B 1}$ and $T_{B 2}$ are structural breaks dates; $k$ lag-length. Critical values for breaks (in intercept and trend jointly) are from Lee-Strazicich (2004).

Using AIC (Table-2), we pick lag-2. When income inequality, economic growth, education and trade openness are the forcing variables, the F-statistic confirms cointegration with structural breaks in Pakistan, further confirmed by the Gregory-Hansen cointegration test.

Table-2: Results of ARDL Test

\begin{tabular}{|l|l|l|l|l|l|l|}
\hline \multicolumn{2}{|l|}{ Bounds Testing to Cointegration } & \multicolumn{3}{l|}{ Diagnostic tests } \\
\hline Estimated Models & Optimal-lags & F-statistics & $\begin{array}{c}\text { Break } \\
-Y \text { Year }\end{array}$ & $R^{2}$ & Adj- $R^{2}$ & $\mathrm{D}-\mathrm{W}$ \\
\hline$T R_{t}=f\left(I_{t}, Y_{t}, E_{t}, O_{t}\right)$ & $2,2,2,2,1$ & $10.349 *$ & 1997 & 0.776 & 0.4568 & 2.373 \\
\hline$I_{t}=f\left(T R_{t}, Y_{t}, E_{t}, O_{t}\right)$ & $2,2,2,1,2$ & 1.848 & 1998 & 0.819 & 0.7869 & 2.011 \\
& & & & 9 & & 0 \\
\hline
\end{tabular}


Shahbaz et al. / Income Inequality and Domestic Terrorism Nexus

\begin{tabular}{|c|c|c|c|c|c|c|}
\hline$Y_{t}=f\left(T R_{t}, I_{t}, E_{t}, O_{t}\right.$ & $2,2,2,2,2$ & 1.022 & 1997 & $\begin{array}{l}0.699 \\
6\end{array}$ & 0.2145 & $\begin{array}{l}2.199 \\
2\end{array}$ \\
\hline$E_{t}=f\left(T R_{t}, I_{t}, Y_{t}, O_{t}\right)$ & $2,2,2,2,2$ & 1.533 & 2001 & $\begin{array}{l}0.859 \\
5\end{array}$ & 0.6327 & $\begin{array}{l}2.340 \\
9\end{array}$ \\
\hline$O_{t}=f\left(T R_{t}, I_{t}, Y_{t}, E_{t}\right)$ & $2,2,2,2,2$ & 2.213 & 2003 & $\begin{array}{l}0.737 \\
5\end{array}$ & 0.3136 & $\begin{array}{l}2.209 \\
3\end{array}$ \\
\hline \multirow[b]{2}{*}{ Significance-level } & Critical-values & & & & & \\
\hline & $\begin{array}{l}\text { Lower-bounds } \\
I(0)\end{array}$ & $\begin{array}{l}\text { Upper-bounds } \\
I(1)\end{array}$ & & & & \\
\hline $1 \%$ & 7.527 & 8.803 & & & & \\
\hline $5 \%$ & 5.387 & 6.437 & & & & \\
\hline $10 \%$ & 4.477 & 5.420 & & & & \\
\hline
\end{tabular}

Table-3: Gregory-Hansen Structural Break Co-integration Test

\begin{tabular}{|c|c|c|c|c|c|}
\hline $\begin{array}{l}\text { Estimat } \\
\text { ed } \\
\text { Model }\end{array}$ & $T R_{t}=f\left(I_{t}, Y_{t}, E_{t}, O\right.$ & $I_{t}=f\left(T R_{t}, Y_{t}, E_{t}, O\right.$ & $Y_{t}=f\left(T R_{t}, I_{t}, E_{t}, O\right.$ & $E_{t}=f\left(T R_{t}, I_{t}, Y_{t}, C\right.$ & $O_{t}=f\left(T R_{t}, I_{t}, Y_{t}\right.$, \\
\hline $\begin{array}{l}\text { Break- } \\
\text { Year }\end{array}$ & 1997 & 1998 & 1997 & 2001 & 2003 \\
\hline $\begin{array}{c}\text { ADF T- } \\
\text { statistic } \\
\text { s }\end{array}$ & $-6.037 *$ & $-5.068 * *$ & -3.453 & -2.889 & -4.520 \\
\hline $\begin{array}{c}\mathrm{P}- \\
\text { values }\end{array}$ & 0.0000 & 0.0000 & 0.0262 & 0.500 & 0.0000 \\
\hline \multicolumn{6}{|c|}{$\begin{array}{l}\text { Note: * and**are significance level, } 1 \% \text { and } 5 \% \text { levels respectively. Critical values for the ADF test at } 1 \%, 5 \% \text { and } 10 \% \\
\text { are }-5.13,-4.61 \text { and }-4.34 \text { respectively. }\end{array}$} \\
\hline
\end{tabular}

The long-run elasticities of terrorism are reported in Table-4. (All results are on average and ceteris paribus). A $1 \%$ rise in income inequality increases domestic terrorism by $0.8028 \%$; and is statistically significant at the $1 \%$ level. This is consistent with Derin-Gure and Elveren (2013) for Turkey. A $1 \%$ 
rise in income per-capita leads to a $1.2312 \%$ increase in domestic terrorism and is significant at the $10 \%$ level. This is consistent with Shahbaz et al. (2013). The elasticity of terrorism with respect to education is small and positive; but significant at the $10 \%$ level. This contradicts Jai (2001) who finds a negative link. Krueger et at. (2003) reports no relation. While insignificant, trade openness enhances domestic terrorism.

Table-4: Long-Run results

\begin{tabular}{|c|c|c|c|}
\hline \multicolumn{4}{|c|}{ Dependent Variable: $\ln T E R_{t}$} \\
\hline Variable & Coefficient & Std. Error & t-Statistic \\
\hline Constant & $-16.2150^{*}$ & 2.6854 & -6.0380 \\
\hline $\ln I_{t}$ & $0.8028^{*}$ & 0.2381 & 3.3716 \\
\hline $\ln Y_{t}$ & $1.2312 * * *$ & 0.6449 & 1.9091 \\
\hline $\ln E_{t}$ & $0.1079 * * *$ & 0.0637 & 1.6934 \\
\hline $\ln T O_{t}$ & 0.6158 & 0.4773 & 1.2900 \\
\hline$R^{2}$ & 0.8398 & & \\
\hline$A d j-R^{2}$ & 0.8204 & & \\
\hline F-statistic & $43.2691 *$ & & \\
\hline D.W. & 1.8320 & & \\
\hline Diagnostic Test & F-statistic & P-value & \\
\hline$\chi^{2} N O R M A L$ & 1.3128 & 0.1410 & \\
\hline$\chi^{2}$ SERIAL & 0.1431 & 0.7076 & \\
\hline$\chi^{2} A R C H$ & 1.8228 & 0.1786 & \\
\hline$\chi^{2}$ WHITE & 1.0505 & 0.4230 & \\
\hline$\chi^{2}$ REMSAY & 1.7909 & 0.1836 & \\
\hline
\end{tabular}

The short run results (Table-5) show that the elasticity of domestic terrorism with respect to income inequality is positive and significant at $10 \%$ level, but that of economic growth is positive but 
insignificant. The elasticities of terrorism with respect to education and trade-openness are positive and significant at the $1 \%$ and $5 \%$ respectively.

Table-5: Short-Run Results

\begin{tabular}{|c|c|c|c|}
\hline \multicolumn{4}{|c|}{ Dependent Variable: $\ln T E R_{t}$} \\
\hline Variable & Coefficient & Std. Error & t-Statistic \\
\hline Constant & -0.0108 & 0.0495 & -0.2194 \\
\hline $\ln I_{t}$ & $0.7464 * * *$ & 0.4082 & 1.8282 \\
\hline $\ln Y_{t}$ & 1.0628 & 1.6414 & 0.6475 \\
\hline $\ln E_{t}$ & $0.2812 *$ & 0.0874 & 3.2150 \\
\hline $\ln T O_{t}$ & $0.9315^{* *}$ & 0.4468 & 2.0845 \\
\hline$E C M_{t-1}$ & $-0.8819 *$ & 0.2603 & -3.3876 \\
\hline$R^{2}$ & 0.4847 & & \\
\hline $\operatorname{Adj}-R^{2}$ & 0.4015 & & \\
\hline F-statistic & $5.8319^{*}$ & & \\
\hline D. W Test & 1.9150 & & \\
\hline Diagnostic Test & F-statistic & Prob. Value & \\
\hline$\chi^{2}$ NORMAL & 1.7773 & 0.1338 & \\
\hline$\chi^{2}$ SERIAL & 1.0070 & 0.3777 & \\
\hline$\chi^{2} A R C H$ & 1.9192 & 0.1719 & \\
\hline$\chi^{2}$ WHITE & 0.6341 & 0.7714 & \\
\hline$\chi^{2}$ REMSAY & 1.7090 & 0.1830 & \\
\hline
\end{tabular}


A significant $\mathrm{ECM}_{\mathrm{t}-1}(-0.8819)$ indicates a stable long-run relationship. This estimate also suggests that any short-run deviation from equilibrium is corrected by $88.19 \%$ annually. The short run results pass the diagnostic tests. The model appears well-specified. The CUSUM and CUSUMsq plots show that the parameters are within $5 \%$ critical bounds.

Figure-1: CUSUM Recursive Residuals Plot

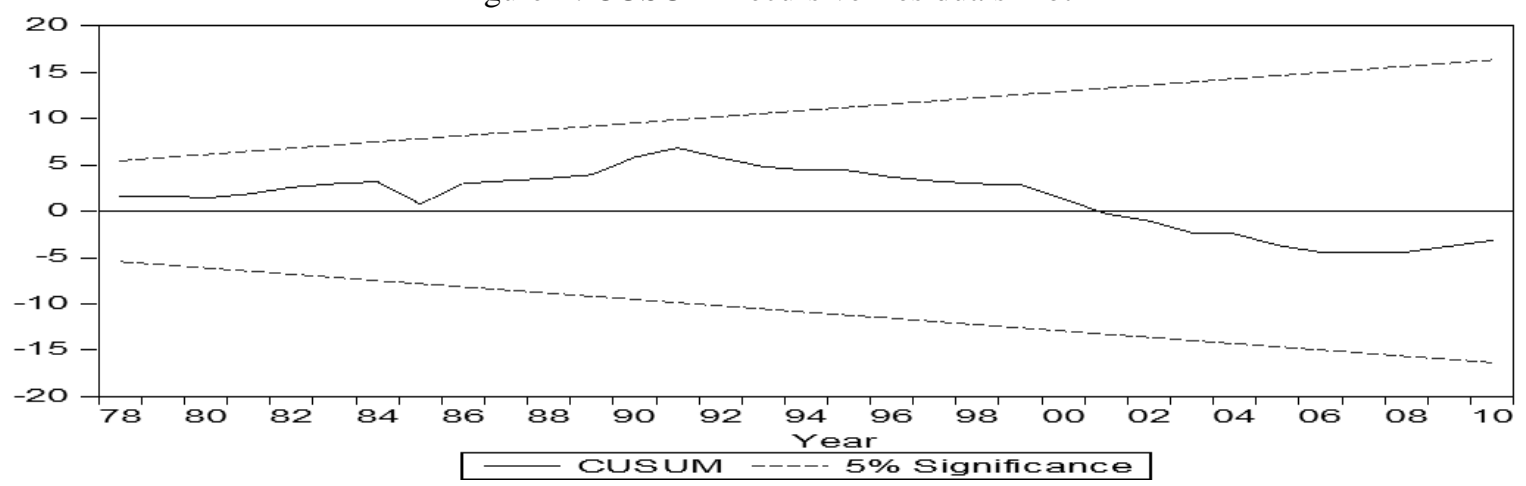

The straight lines represent $5 \%$ critical bounds.

Figure-2: CUSUM of Squares of Recursive Residuals Plot

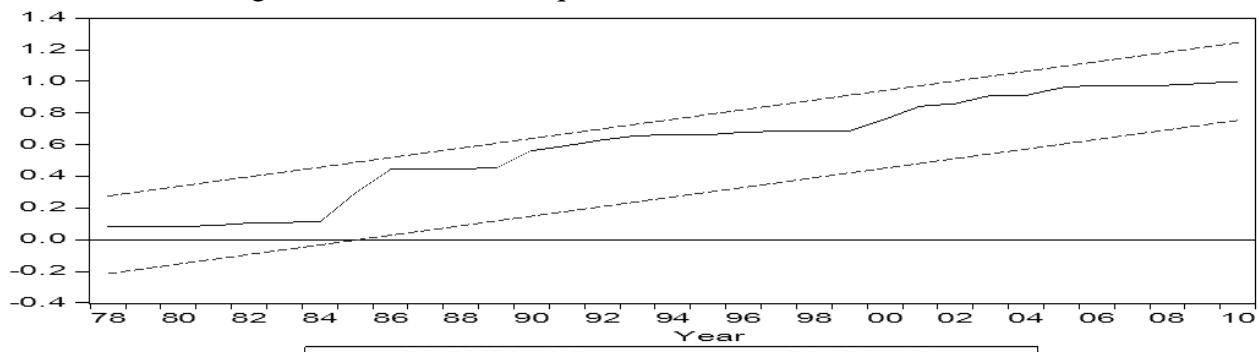

The straight lines represent $5 \%$ critical bounds.

\section{Conclusion and Policy Implications}

The results from ARDL and G-H tests confirm cointegration for Pakistan during 1972-2010 period among the series even with structural break. Lopsided economic growth and unequal access to education have contributed to worsening of income inequality in Pakistan which may have exacerbated terrorism.

Government should adopt comprehensive manpower policy to address terrorism. Unless the fruits of economic growth improve living standards in general, containing terrorism in Pakistan may be hard. Narrowing down of income inequality at all levels will help. Mandating secondary level education in which "good citizenship" is a part of curriculum should help every youth. Policy to absorb educated unemployed is critical for improving self-esteem. Appropriate policy can turn Pakistan into be an outsourcing hub for tech-intensive products. Export of human capital can be part of overall manpower policy to boost foreign currency earning which then can be efficiently invested in productive sectors of the economy and create more employment. 


\section{References}

Abadie, A. (2006). Poverty, political freedom, and the roots of terrorism. American Economic Review 96:50-56.

Bhagwati, J., and T.N., Srinivasan, (2002). Trade and Poverty in the Poor Countries. The American Economic Review, 92:180-83.

Blomberg, S. B., Hess, G. D., Weerapana, A. (2004). Economic conditions and terrorism. European Journal of Political Economy, 20, 463-478.

Caruso, R., Schneider, F., (2013). Brutality of Jihadist terrorism. A contest theory perspective and empirical evidence in the period 2002-2010. Journal of Policy Modeling, 35, 685-96.

Derin-Gure, P., Elveren, A. Y., (2013). Does income inequality derive the separatist terrorism in Turkey? Defense and Peace Economics. Forthcoming issue.

Frey, B.S., Luechinger, S., Stutzer, A. (2007). Calculating tragedy: assessing the costs of terrorism. Journal of Economic Surveys, 21, 1-24.

Freytag, A., Kruger, J. J., Schneider, F., (2011). The origins of terrorism cross country estimates on socio economic determinants of terrorism. European Journal of Political Economy, 27, 5-16.

Jai, J. J., (2001). Getting at the roots of terrorism. Christian Science Monitor 10, Dec., 2001.

Krieger, T., Meierrieks, D. (2011). What causes terrorism? Public Choice, 147:3-27.

Krueger, A. B. and Maleckova, J. (2003). Education, poverty, and terrorism: Is there a causal connection? Journal of Economic Perspectives, 17, 119-144.

Kurrild-Klitgaard, P., Justesen, M.K., Klemmensen, R., (2006). The political economy of freedom, democracy and transnational terrorism. Public Choice, 128, 289-315.

Lee, J. and Strazicich, M.C. (2004). Minimum LM unit root test with one structural break. Appalachain State University, Department of Economics, Working Paper No: 17.

Narayan, P.K., (2005). The saving and investment nexus for China: evidence from co-integration tests. Applied Economics, 37, 1979-1990.

Pesaran, M.H., Shin, Y., Smith, R. J., (2001). Bounds testing approaches to the analysis of level relationships. Journal of Applied Econometrics, 16, 289-326.

Piazza, J.A. (2006). Rooted in poverty? Terrorism, poor economic development, and social cleavages. Terrorism and Political Violence, 18, 159-177.

Ross, J.I., (1993). Structural causes of oppositional political terrorism: towards a causal model. Journal of Peace Research, 30, 317-329. 
Shahbaz et al. / Income Inequality and Domestic Terrorism Nexus

Shahbaz, M., Shabbir, M.S., Malik, M.N., Wolters, M. E., (2013). An analysis of a causal relationship between economic growth and terrorism in Pakistan. Economic Modelling 35:21-29. 